\title{
Peran Wanita dalam Peningkatan Nilai Tambah Ekonomi Sampah Rumah Tangga melalui Pengelolaan Bank Sampah di Lingkungan Perumahan Larangan Mega Asri Sidoarjo
}

\author{
Ni Ketut Yulia Agustini ${ }^{1}$, Indahwati ${ }^{2}$ dan Dana Aditya ${ }^{3}$ \\ 123 Program Studi Manajemen, Universitas Wijaya Kusuma Surabaya, Dukuh Kupang XXV No. 54, \\ Surabaya, Indonesia, 60225
}

Correspondence: Dana Aditya (dana.aditya@gmail.com) Received: 300721 - Revised: 040821 - Accepted: 040821 - Published: DD MM YY

\begin{abstract}
Abstrak. Persepsi masyarakat tentang sampah, kebiasaan masyarakat yang masih membuang sampah sembarangan dan terbatasnya lahan TPA (Tempat Pembuangan Akhir) menjadi persoalan yang hingga saat ini belum bisa ditangani. Manusia yang menghasilkan sampah maka seharusnya manusia tersebut yang harus bertanggung jawab untuk mengelolanya sendiri. Kebanyakan masyarakat hanya melihat sampah sebagai barang yang remeh, tidak berguna, tidak berharga, menjijikkan, dan sumber kuman serta penyakit. Bank Sampah menjadi salah satu solusi yang efektif untuk bisa mengurangi jumlah sampah yang dikirim ke TPA. Bank Sampah memberikan manfaat kepada lingkungan sosial dan ekonomi terhadap pengurangan sampah sebelum sampai ke TPA, sekaligus mampu untuk mencipatakan peluang kerja.
\end{abstract}

Kata kunci: zero waste, bank sampah, community development, pemilahan dan pengolahan sampah.

Citation Format: Agustini, N. K. Y., Indahwati, Aditya, D. (2020). Peran Wanita dalam Peningkatan Nilai Tambah Ekonomi Sampah Rumah Tangga melalui Pengelolaan Bank Sampah di Lingkungan Perumahan Larangan Mega Asri Sidoarjo. Prosiding Seminar Nasional Abdimas Ma Chung (SENAM), 2020, Xx-Xx. 


\section{PENDAHULUAN}

Kondisi pandemi Covid-19 menuntut ibu sebagai wanita di rumah untuk berpikir kreatif dan mandiri untuk mencukupi kebutuhan keluarga. Peran ibu sebagai untuk memenuhi kebutuhan keluarga dilakukan dengan berwirausaha, bekerja kantoran, buruh, bahkan mengerjakan pekerjaan berat. Disinilah peran ibu dalam pemberdayaan ekonomi untuk meningkatkan kesejahteraan ekonomi keluarga (Dan et al., 2012). Seorang ibu berperan aktif untuk mengurus rumah tangga serta sebagai penopang ekonomi keluarga, berdasarkan izin suami agar lancar dalam pekerjaan (Zuhdi, 2019).

Tugas pokok seorang ibu sebagai pengurus rumah tangga, perekonomian keluarga, pendidikan anak menunjukkan peran vitalnya terhadap kesejahteraan keluarga. Seperti yang terjadi saat pandemi Covid-19 dimana ibu-ibu rumah tangga berusaha untuk meningkatkan penghasilannya dengan ikut pengolahan sampah organik dan anorganik (Ankesa et al., 2016). Peluang usaha pengolahan sampah organik dan anorganik mampu untuk meningkatkan perekonomian keluarga tanpa harus keluar terlalu lama dari rumah, sehingga mempunyai waktu lebih dalam mendidik anak. Peningkatan kemandirian ekonomi keluarga melalui pengolahan sampah berdampak pada tingginya kesehatan lingkungan (Puspitawati et al., 2012).

Motivasi ibu-ibu dalam pengolahan sampah tidak hanya untuk membantu ekonomi keluarga namun juga peningkatan kualitas lingkungan sekitar. Sampah bisa menghasilkan uang dengan mengolahnya menjadi kompos, daur ulang plastik, pakan perikanan, dan berbagai bentuk lain. Permasalahan yang dihadapai adalah kurangnya motivasi dan pemahaman untuk melakukan pengolahan sampah keluarga secara mandiri. Sampah dikelompokan menjadi dua yaitu organik dan anorganik (Badan Pusat Statistik, 2018), pengolahan sampah organik lebih susah dibandingkan sampah anorganik dimana adanya bau menyengat dan munculnya belatung. Sampah Organik muncul dari bahan penyusun tumbuhan dan hewani melalui pengolahan pertanian, perikanan, perkebunan atau lainnya. Sampah organik akan mudah diuraikan secara alami namun hal ini membutuhkan proses yang cukup lama dan seringkali tidak familiar bagi ibu-ibu rumahtangga ketika menghadapi bau menyengat dan belatung (Sulistyorini, 2005). Sampah anorganik diperoleh dari hasil pengolahan sumber daya alam tak terbarui seperti mineral dan minyak bumi untuk penggunaan bahan plastik dan aluminium rumah tangga. Bahan anorganik mempunyai sifat untuk tidak mudah terurai secara alami dibandingkan sampah organik (Puspitawati, 2012). 
Pengolahan sampah anorganik untuk peningkatan nilai tambah ekonomi keluarga dalam pengelolaan hasil penjualan sampah anorganik rumah tangga melalui bank sampah. Penghasilan diperoleh dari pemilahan/pengelompokkan sampah berdasarkan kategorinya dalam upaya untuk peningkatan nilai ekonomi yang berbeda di setiap jenis sampahnya. Bank sampah dipergunakan untuk tempat menabung sampah yang telah terpilah, dimana sampah yang ditabung hanya sampah yang punya nilai ekonomis sedangkan yang tidak memiliki nilai ekonomis akan dibuang (Kristina, 2014). Cara kerja bank sampah menyerupai konsep bisnis perbankan dimana ada nasabah, pencatatan pembukuan dan manajemen risiko, perbedaanya adalah pada sampah yang disetorkan. Sampah yang sudah dipilih dan dikelola harus dijalankan oleh petugas yang berjiwa mandiri dan dapat dipercaya dalam mengembangakan usaha bank sampah untuk meningkatkan pendapatan rumah tangga (Suryani, 2014). Pola kerja bank sampah dikelola dengan dasar keaktifan ibu-ibu rumah tangga, untuk menstimulasi keaktifannya maka diberikan hadiah kepada orang yang memilah dan menyetorkan sampah rumah tangga. Adopsi konsep perbankan kepada bank sampah berdasarkan pendekatan risiko dimana selalu memperhatikan fluktuasi harga sampah anorganik di pasaran. Bank sampah tidak hanya berperan untuk program penghijauan lingkungan, namun pengelolaan sampah mampu untuk mengedukasi program gemar menabung bagi anak sekolah dasar hingga menengah atas. Bank sampah juga berfungsi untuk membentuk komunitas masyarakat untuk peduli dan memperhatikan lingkungan hidup.

Pada pengeabdian masyarakat ini berdasarkan pemahaman dari theory of planned behavior (TPB) digunakan sebagai landasan teori untuk melihat pengaruh sikap terhadap perilaku, kontrol perilaku dan norma subjektif pada niat ibu-ibu rumah tangga untuk menabung di bank sampah. 


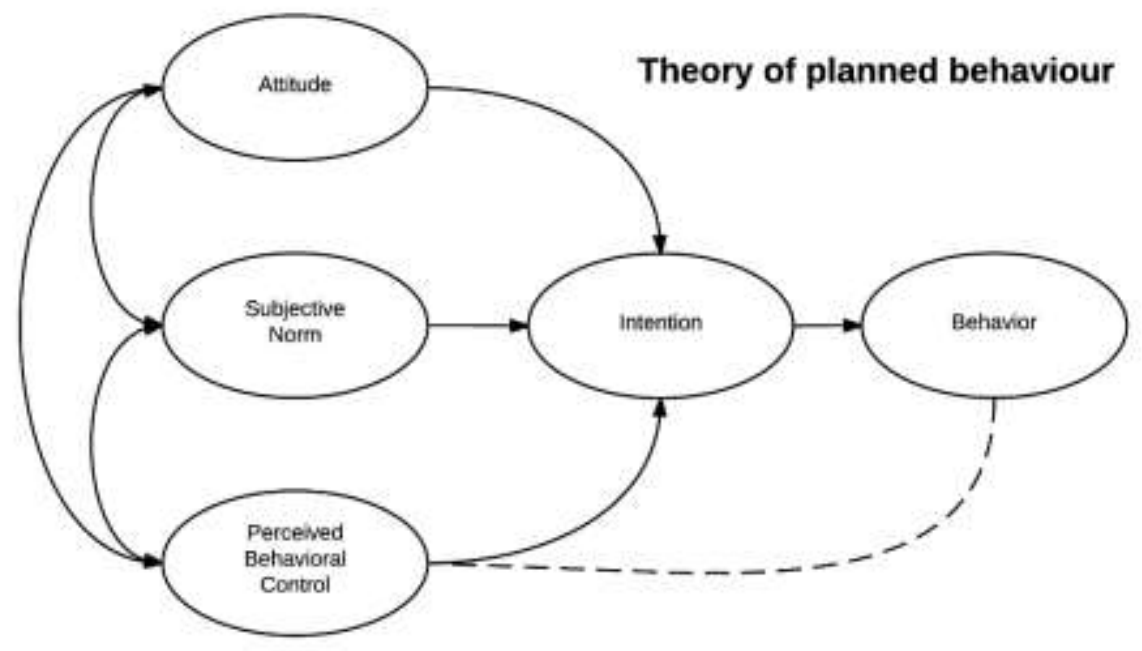

Gambar 1. Theory Planned Behaviour Sumber: Ajzen, 2005

Teori ini menjelaskan perspektif kepercayaan seseorang untuk bertingkah laku berdasarkan karakteristik, kualitas dan atribut tertentu dalam membentuk intensi berperilaku (I. Ajzen et al., 2005). Intensi atau niat merupakan keputusan untuk berperilaku secara sadar maupun tidak sadar berdasarkan sikap, norma subyektif dan kontrol perilaku. Teori planned behavior cocok digunakan untuk mendeskripsikan perilaku apapun yang memerlukan perencanaan (Icek Ajzen, 2011).

Teori planned behavior menjelaskan sikap perilaku merupakan dasar untuk memprediksi perilaku, pertimbangan sikap seseorang terhadap norma subyektif yang dipergunakan untuk malaukan kontrol perilaku seseorang. Sikap positif dari orang sekitar serta adanya persepsi kesenangan melalui aktivitas interaksi sosial akan meningkatkan niat seseorang untuk berperilaku positif (Ajzen, 2005). Seseorang yang bersikap positif pada program komunitas zero waste, karena mendapat dukungan dari lingkungannya serta munculnya persepsi kebahagian dalam suatu komunitas bank sampah.

\section{METODE PELAKSANAAN}

Edukasi kepada masyarakat terhadap peningkatan pelaksanaan sistem pengelolaan sampah terpadu dalam program zero waste yang menyatukan kemitraan operasional, manajemen lingkungan, peraturan dan pembiayaan antara pemerintah dengan masyarakat. Pemahaman akan sampah dan sumber sampah yang memunculkan dampak negatif dan permasalahan sosial akan muncul dimana pengelolaan sampah tidak berjalan baik. 
Meningkatkan kemampuan masyarakat untuk melakukan pemilahan sampah berdasarkan kelompoknya yaitu organik dan anorganik (Badan Pusat Statistik, 2018):

1. Sampah Organik, terdiri dari sisa kegiatan rumah tangga, perkebunan, perikanan atau yang lainnya dan dapat diuraikan dalam proses alami. Sampah rumah tangga sebagian besar merupakan bahan organik berupa sisa tepung, sayuran, kulit buah, dan daun.

2. Sampah Anorganik, terdiri dari plastik dan aluminium, dimana zat anorganik tidak dapat dengan cepat untuk diproses secara alami misalnya botol, botol plastik, tas plastik, dan kaleng.

Karakter sampah rumah tangga dapat dikenali berdasarkan jumlah sampah, komposisi sampah, dan proses pembusukan yang terjadi.

Karakteristik sampah sangat dipengaruhi apakah sampah tersebut hanya dikumpulkan dan dibuang atau sudah melalui proses daur olang ataupun pengolahan agar memberikan dampak ekonomis yang dipengaruhi oleh karakteristik penduduk, ekonomi dan gaya hidup masyarakat. Kebutuhan akan sistem pengelolaan sampah terpadu maka pemerintah secara total ataupun mandiri bermitra dengan masyarakat untuk mengakomodasi proses pengolahan sampah. Menurut (Perdana et al., 2016) berdasarkan sumbernya maka sampah digolongkan menjadi sampah domestik dan non domestik dimana sampah domestik dalam pengelolaannya membutuhkan kesadaran orang di lingkungan tersebut.

Pengelolaan sampah untuk mendapatkan manfaat ekonomis berdasarkan unsur biologis dan kimia yang akan mengalami proses perubahan dan waktu diklasifikasikan sebagai berikut:

1. Sampah busuk akan menghasilkan gas metan dan $\mathrm{H} 2 \mathrm{~S}$ dengan sifat beracun dan mudah terbakar. Sampah ini bisa diolah menjadi pupuk bahkan sumber energi terbarukan.

2. Sampah yang tidak dapat membusuk seperti plastik, logam, gelas, karet dan lain-lain. Sampah tersebut tidak hanya langsung dijual namun juga bisa sebagai karya seni bahkan sisanya dapat digunakan sebagai campuran asapal maupun batako untuk genteng rumah.

3. Sampah yang berupa debu atau abu sisa dari hasil sisa pembakaran.

4. Sampah yang berbahaya bagi kesehatan, yakni sampah B3 mengandung konsentrasi kimian yang dapat meningkatkan mortalitas dan morbiditas. Limbah B3 juga berakibat kepada munculnya penyakit seperti kanker, yang muncul secara tidak sengaja ketika 
mengkonsumsi sumber makanan dan minuman yang sudah tercemar dalam jangka waktu tertentu.

Limbah berbeda dengan sampah dimana limbah memerlukan pengelolaan khusus agar tidak mencemari lingkungan. Perbedaan sampah dan limbah dapat dilihat dari asal, wujud, tingkat pencemaran, kandungan di dalamnya dan metode pengolahannya.

\section{HASIL DAN PEMBAHASAN}

Diperoleh hasil masih banyaknya sampah organik yang dibuang ke TPA sehingga memberikan beban lebih kepada pengolahan sampah akhir. Maka disusunlah flowchart pengelolaan sampah rumah tangga sebagai kegiatan utama pendirian bank sampah. Bank sampah tidak hanya melakukan aktivitas kegiatan sosial pengolahan sampah rumah tangga namun juga bergerak ke arah komersialisasi hasil pengolahan sampah.

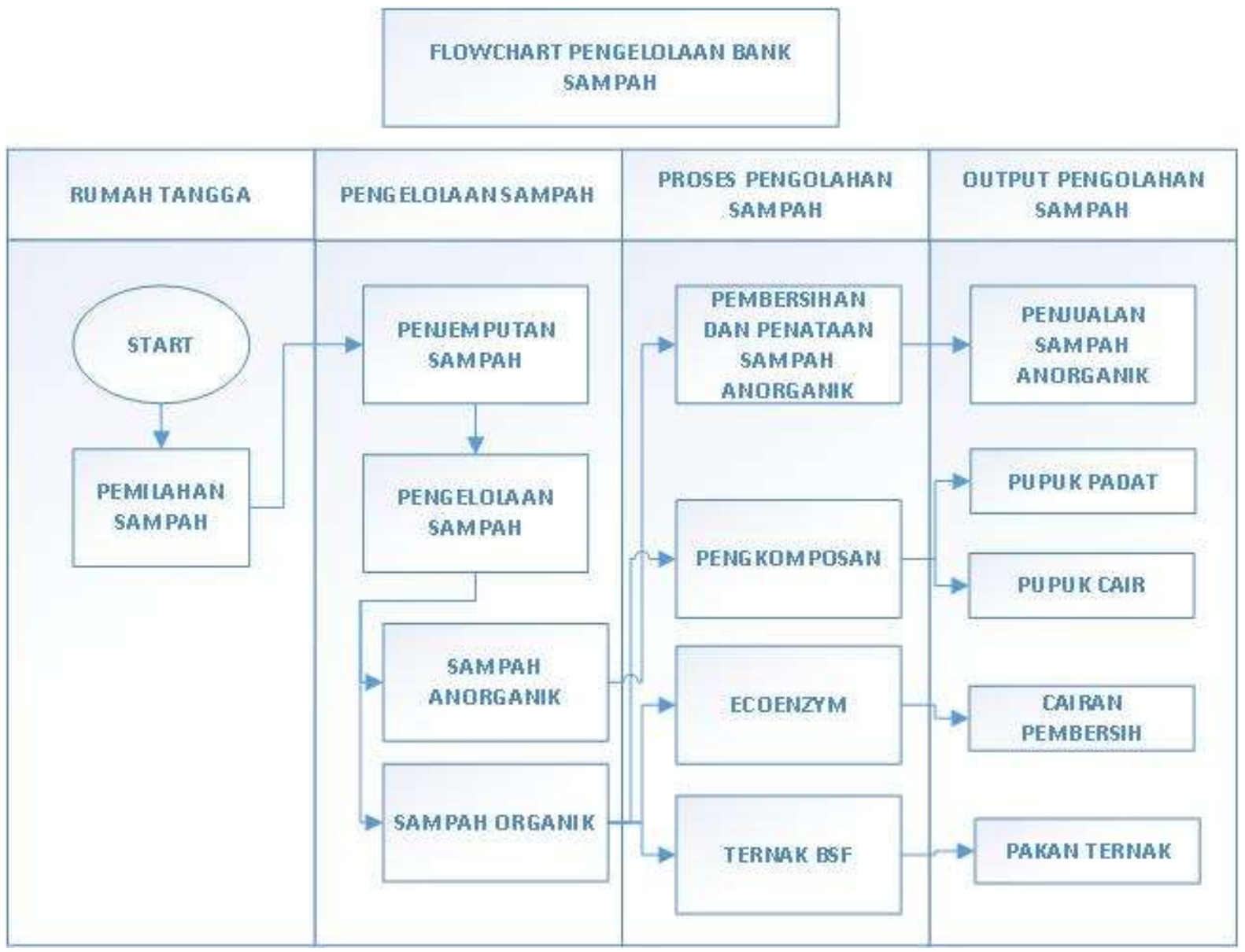

Gambar 2. Flowchart Pengelolaan Sampah

Proses Pengolahan Sampah 
Sampah padat yang bertumpuk banyak tidak dapat teruraikan dalam waktu yang lama akan mencemarkan tanah. Dekomposisi sampah dapat terjadi secara aerobik, dilanjutkan secara fakultatif dan secara anaerobik apabila oksigen habis. Dekomposisi secara anaerobik akan menghasilkan cairan yang disebut Leachate beserta gas. Leachate atau lindi adalah cairan yang mengandung zat padat yang tersuspensi yang sangat halus dan hasil penguraian mikroba yang biasanya terdiri atas $\mathrm{Ca}, \mathrm{Mg}, \mathrm{Na}, \mathrm{K}, \mathrm{Fe}$, khlorida, Sulfat, fosfat, $\mathrm{Zn}, \mathrm{Ni}, \mathrm{CO}$, $\mathrm{H} 2 \mathrm{O}, \mathrm{N} 2, \mathrm{NH} 3, \mathrm{H} 2 \mathrm{~S}$, asam organik dan H2. Berdasarkan kualitas sampahnya leachate atau lindi bisa pula didapat mikroba patogen, logam berat dan zat lainnya yang berbahaya.

Sampah organik dapat diproses kembali menjadi berbagai produk yang memiliki nilai tambah ekonomi sebagai contohnya adalah lindi yang berfungsi sebagai pupuk organik. Tumpukan sampah organik tidak hanya menghasilkan lindi namun juga gas metan yang dapat digunakan sebagai bahan bakar alternatif. Sampah anorganik yang tidak laku seperti bungkus minuman, stereofoam dan sobekan plastik bisa diolah lagi untuk karya seni, campuran batako bahkan genting rumah.

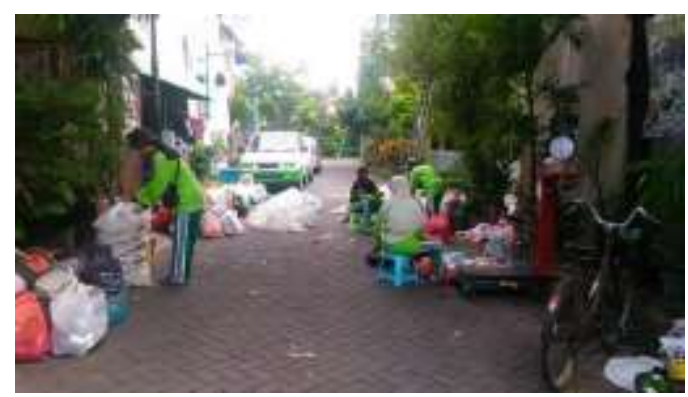

Gambar 3. Kegiatan pengelolaan sampah anorganik

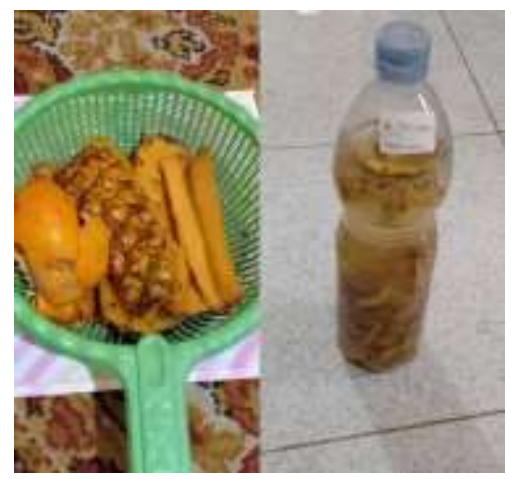

Gambar 4. Pengolahan limbah kulit buah menjadi eco enzyme 


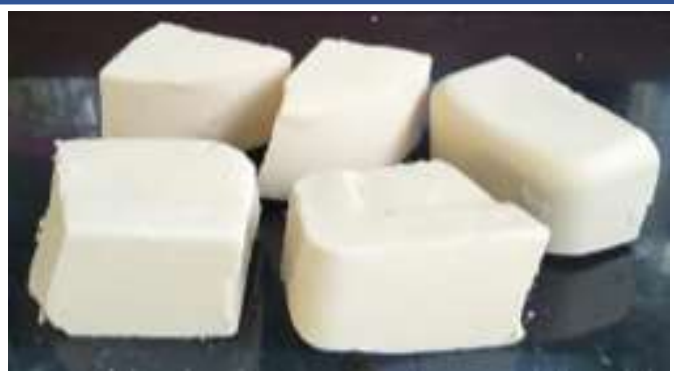

Gambar 5. Hasil sabun dari pengolahan sampah minyak jelantah setelah 1 bulan menghilangkan sisa bahan kimia yang digunakan

Lamanya proses pengolahan sampah organik dan dibutuhkannya peningkatan nilai tamabah sampah anorganik, sangat membutuhkan peran serta masyarakat dalam program pengelolaan sampah. Salah satu pendekatan pada masyarakat untuk dapat membantu program pemerintah dalam kebersihan adalah membiasakan masyarakat pada tingkah laku yang sesuai dengan program persampahan yaitu merubah persepsi masyarakat terhadap pengelolaan sampah yang tertib, lancar dan merata, merubah kebiasaan masyarakat dalam pengelolaan sampah yang kurang baik dan faktor-faktor sosial, struktur dan budaya setempat.

Pengabdian Masyarakat pengelolaan bank sampah yang dilakukan di tahun pertama ini berdasarkan theory planned behavior (TPB) berada pada tahap edukasi warga terkait subyektifitas, attitude dan kontrol perilaku zero waste. Warga dibangun subyektifitas, attitude dan kontrol perilakunya pada sampah organik yang selama ini terkesan menjijikkan dan kotor dalam pengolahannya. Masih adanya kesulitan warga untuk melakukan proses pengolahan sampah anorganik karena adanya kesan-kesan negatif yang dimuncuilkan darinya seperti belatung, bau dan tidak ada waktu.

\section{KESIMPULAN}

Berdasarkan pada peninjauan yang telah dilakukan bahwa warga di RW 08 Perum Larangan Mega Asri terdiri dari 10 RT telah mempunyai pemahaman yang baik mengenai sampah anorganik. Yang dapat dibuktikan bahwa warga telah mempunyai bank sampah untuk proses pemilihan dan pemilahan sampah anorganik. Hal ini tentunya menunjukkan adanya kepedulian dan kesadaran masyarakat tentang pentingnya pengelolaan sampah dan mengurangi jumlah sampah yang dikirm ke TPA/Tempat Pembuangan Sampah.Warga RW 08 telah memiliki bank sampah, yang telah menghasilkan keuntungan ekonomi, namun hanya pengumpulan dan penjualan sampah anorganik berupa sampah plastik, kaleng dan sebagainya secara langsung. Dalam rangka menciptakan kemandirian dalam pengelolaan 
sampah, tentunya penting untuk memahami manajemen pengelolaan sampah secara total baik anorganik maupun organik.

\section{UCAPAN TERIMA KASIH}

Ucapan terima kasih ditujukan kepada semua pihak yang terlibat dalam pembuatan naskah. Ucapan terima kasih dapat pula ditujukan kepada LPPM dan Universitas Wijaya Kusuma Surabaya.

\section{DAFTAR PUSTAKA}

Ajzen, I. (2011). The theory of planned behaviour: Reactions and reflections. Psychology \& Health, 26(9), 1113-1127. https://doi.org/10.1080/08870446.2011.613995

Ajzen, I., \& Fishbein, M. (2005). The Influence of Attitudes on Behavior. In D. Albarracín, B. T. Johnson, \& M. P. Zanna (Eds.), The handbook of attitudes (pp. 173-221). Lawrence Erlbaum Associates Publishers..

Ankesa, H. A., Amanah, S., \& Asngari, P. S. (2016). Partisipasi Kelompok Perempuan Peduli Lingkungan dalam Penanganan Sampah di Sub DAS Cikapundung Jawa Barat. Jurnal Penyuluhan, 12(2), 105. https://doi.org/10.25015/penyuluhan.v12i2.10929

Dan, E., \& Perempuan, P. (2012). Ekofeminisme Dan Peran Perempuan Dalam Lingkungan. Indonesian Journal of Conservation, 1(1), 49-60.

Dongoran, Hamdani Harahap, Tarigan, U. (2018). Jurnal Administrasi Publik Implementasi Peraturan Walikota Medan tentang Unit Implementation of Mayor Regulation of Medan on Technical Implementation Unit of Cleaning Service and Waste Bank. Jurnal Administrasi Publik, 8(1), 47-64.

Dwiyanto, B. M. (2011). Model Peningkatan Partisipasi Masyarakat Dan Penguatan Sinergi Dalam Pengelolaan Sampah Perkotaan *. Jurnal Ekonomi Pembangunan: Kajian Masalah Ekonomi Dan Pembangunan, 12(2), 239. https://doi.org/10.23917/jep.v12i2.196

Kristina, H. J. (2014). Model Konseptual Untuk Mengukur Adaptabilitas Bank Sampah Di Indonesia.J@Ti Undip : Jurnal Teknik Industri, 9(1), 19-28. https://doi.org/10.12777/jati.9.1.19-28

Melyanti, I. M. (2014). Kebijakan dan Manajemen Publik Pola Kemitraan Pemerintah, Civil Society, dan Swasta dalam Program Bank Sampah di Pasar Baru Kota Probolinggo. Kebijakan Dan Manajemen Publik, 2(1), 1-9. Retrieved from www.paskomnas.com

Mirwan, M. (2008). Optimasi Pengelolaan Sampah Di Kampus Upn “Veteran ” Jawa Timur. Jurnal Rekayasa Perencanaan, 4(2), 1-10. Retrieved from http://eprints.undip.ac.id/32520/1/2.Jurnal_Kajian_Pengelolaan_Sampah_Kampus__Edo_dkk.pdf

Perdana, H. D., Hananto, S. T., \& Murni, S. (2016). Peningkatan Sarana Prasarana 
Pengelolaan Sampah Rumah Tangga Desa Doplang Kabupaten Boyolali. Pengabdian Kepada Masyarakat, 22(4), 1-9.

Puspitawati, Y., \& Rahdriawan, M. (2012). Kajian Pengelolaan Sampah Berbasis

Masyarakat dengan Konsep 3R (Reduce, Reuse, Recycle) di Kelurahan Larangan

Kota Cirebon. Jurnal Pembangunan Wilayah \& Kota, 8(4), 349.

Sulistyorini, L. (2005). Pengelolaan Sampah dengan Cara Menjadikannya Kompos. Jurnal Kesehatan Lingkungan Unair, 2(1), 77-84.

Suryani, A. S. (2014). PERAN BANK SAMPAH DALAM EFEKTIVITAS PENGELOLAAN SAMPAH (STUDI KASUS BANK SAMPAH MALANG). Sanitasi Lingkungan, 5(1), 71-84.

Zuhdi, S. (2019). Membincang Peran Ganda Perempuan Dalam Masyarakat Industri. Jurnal Jurisprudence, 8(2), 81-86. https://doi.org/10.23917/jurisprudence.v8i2.7327

(C) 2021 by authors. Content on this article is licensed under a Creative Commons Attribution 4.0 International license. (http://creativecommons.org/licenses/by/4.0/). 